\title{
IN VITRO PHYTOREMEDIATION OF PERSISTENT ORGANIC POLLUTANTS BY Helianthus annuus L. PLANTS
}

\author{
Marcos V. de Almeida ${ }^{a}$, Sandra R. Rissato ${ }^{\mathrm{b},{ }^{*}}$, Mário S. Galhiane ${ }^{\mathrm{b}}$, João R. Fernandes ${ }^{\mathrm{b}}$, Paulo C. Lodic and Marcelo C. de \\ Campos $^{\mathrm{d}}$ \\ aDepartamento de Química, Instituto Tecnológico da Aeronáutica, 12228-900 São José dos Campos -SP, Brasil \\ bDepartamento de Química, Universidade Estadual Paulista, 17033-360 Bauru - SP, Brasil \\ 'Departamento de Engenharia Civil, Universidade Estadual Paulista, 17033-360 Bauru - SP, Brasil \\ ${ }^{d}$ Departamento de Engenharia Mecânica, Universidade Estadual de São Paulo, 17033-360 Bauru - SP, Brasil
}

Recebido em 09/06/2017; aceito em 28/11/2017; publicado na web em 18/12/2017

\begin{abstract}
Plant model systems are needed to properly conduct basic laboratory studies prior to field applications of phytoremediation. In vitro plant cultures are a useful tool for such research. This study focuses on the removal and/or degradation of 24 persistent organic pollutants under in vitro conditions by Helianthus annuus L (sunflower). The main purpose of exploiting this plant for phytoremediation process is due to its strong adaptability to adverse environments conditions such as resistance to pests, disease, and others. The study of bioremediation effects of all chemical molecules under in vitro conditions showed promising results. Sixteen out of twenty-four compounds evaluated reached up to $87 \%$ for remediation. The highest accumulation of pollutants was observed in the roots, showing that these results are consistent with the current literature. Through the study, it was observed effective absorption of POPs with $\log K_{\text {ow }}$ ranging from 4.50 to 6.91. Sunflower phytoremediation process efficiently detected heptachlor, aldrin, heptachlor epoxide, trans-chlordane, chlordane, dieldrin, DDE, DDT, methoxychlor, mirex and decachlorobiphenyl.
\end{abstract}

Keywords: phytoremediation; Helianthus annuus L; POPs.

\section{INTRODUCTION}

In the last twenty years, Persistent Organic Pollutants (POPs) have been extensively analyzed and described in the literature. POPs effects are considered bioaccumulation factors of high toxicity and high environmental accumulation. Furthermore, many studies are focused on their widespread distribution and their carcinogenic effect. Due to their physical-chemical properties, and environmental factors, human health can be affected. ${ }^{1}$

Several well-known factors such as application of POPs during agricultural practice, or due to plant metabolism and aging can result in soil contamination. Regardless of the causes, the removal of these molecules from nature is a high priority because of the contamination risk, the environment toxicity and the hazard to human health. ${ }^{2}$ For this purpose, techniques such as phytoremediation, bioremediation, enzymatic degradation or others chemical methods have been applied to remove, remedy or destroy these pollutants. ${ }^{3}$ Phytoextraction and phytostimulation are considered the main mechanisms of remediation processes. ${ }^{4}$ Phytoextraction involves the uptake of contaminants by the plant root system to be phytocompartmented, phytovolatilized, phytoexudated or phytodegradated. ${ }^{3}$ Phytostimulation or rhizodegradation is the breakdown of xenobiotics through microbial activity stimulated by the release of certain plant compounds in the soil. ${ }^{5}$ These mechanisms can be influenced by the density of remedial species, since the increase of plant root system activity and plant transpiration may possibly enhance xenobiotics absorption due to the development of microorganisms in the rhizosphere. ${ }^{6}$

The growth of plant cells and tissues in vitro is a particularly valuable tool to study the complex interaction among plants, soil and microorganisms associated to plant roots. In vitro cultures can be used to investigate the plants response to pollutants concerning

*e-mail: srissato@fc.unesp.br the action of specific enzymes, organic compounds, transporters, or peptides. ${ }^{7,8}$

Helianthus annuus L. also known as sunflower is a plant species of Asteracae family which have been largely used to human and animal nutrition for over 1000 years. The sunflower oil is extracted from seeds and is mainly composed of esterified fatty acids. Due to the good oil content in the seeds, Helianthus annuus L. is extensively studied as an alternative source for biodiesel production in Brazil. ${ }^{9}$ Because sunflower is a common and easy plant to grow, there is no great research interest in establishing a complete in vitro protocol for commercial purposes. The mechanized seeding for this species and low cost advantages of the seeds surpassed the in vitro culture of germination. ${ }^{10}$ Sunflower has been implemented as alternative crop for corn and soybeans in tropical countries because of its fast growth and high amount of nitrobacteria in rhizosphere. Studies on these alternative crops detected the presence of agrochemicals previously used on fruits and sunflower biomass. These findings indicate a possible phytoextraction process of residues from the soil to plant parts. ${ }^{11}$

The use of sunflower in phytoremediation processes is widely reported in the literature since it meets many requirements for this purpose. Several studies have shown the use of sunflower in remediation processes of toxic elements that are difficult to be removed as iron, uranium and other inorganic environmental contaminants. ${ }^{12,13}$ The majority of works focused on the uptake of heavy metals by sunflower, because of its ability to accumulate metals in higher concentrations in comparison to other vegetables. ${ }^{14}$

There are some in vitro researches presenting positive results of sunflower phytoremediation of antibiotics such as Tetracycline and Oxytetracycline. Gujarathi et al. ${ }^{15}$ related the accumulation of these compounds in hairy root cultures of Helianthus annuus L.. Furthermore, sunflower has been successfully used as an effective phytostabilization agent since it decreases the concentration of many volatile organic compounds such as benzene, toluene, xylene (BTX) and polycyclic aromatic hydrocarbons $(\mathrm{PAH}) .{ }^{16,17}$ 
This high ability to remove toxic compounds from the soil associated with the adaptability to adverse environment makes sunflower a promising tool for phytoremediation research. This work focuses on the removal of 24 persistent organic pollutants under in vitro culture of Helianthus annuus $\mathrm{L}$ (sunflower).

\section{EXPERIMENTAL}

\section{Reagents, solvents, materials and reference pesticide standards}

In order to eliminate possible interferences, all the glasses were washed and treated systematically following sequence:running water, soak for about $12 \mathrm{~h}$ in $10 \%$ aqueous solution of alkali Extran detergent, water, distilled water and purified water. All the materials were rinsed with acetone and taken to the oven at $150{ }^{\circ} \mathrm{C}$ for $1 \mathrm{~h}$.

All special grade for pesticide residue analysis as toluene, n-hexane and ethyl acetate were purchased from Mallinckrodt Baker Inc. (Phillipsburg, NJ, USA). Sodium sulfate was supplied by Merck.

C-18 Sep-Pak $\left(200 \mathrm{mg} / 3 \mathrm{~cm}^{3}\right)$ cartridges were purchased from Waters (Milford, MA, USA), while Bond Elut Florisil cartridges (500 $\mathrm{mg}$ ) were provided by Varian (Harbor City, CA, USA). Purified water was obtained from a MilliQ water purification system (Millipore, Bedford, MA, USA).

The mix of 24 organochlorine pesticides standards were purchased from Absolute Standards, Inc. (Connecticut, USA) in the concentration of $1000 \mu \mathrm{g} \mathrm{mL} \mathrm{m}^{-1}$ in toluene/hexane. Stock and working pesticides solutions were prepared by dilution in toluene/n-hexane $(1: 1, \mathrm{v} / \mathrm{v})$.

\section{Sunflower, Helianthus annuus L.}

Seeds were obtained from Helianthus annuus L. grown in a greenhouse under ideal aseptic conditions. The greenhouse follows the agricultural requirements as controlled environment lighting conditions, irrigation and essential nutrients to harvest the seeds.

Sunflowers were grown in the greenhouse under optimal experimental conditions. Plants were (individually) grown in flexible pots of $10 \mathrm{~L}$ to seedling containing a mixture of clay (30\%), organic substrate $(40 \%)$ and expanded clay coarse grained $(30 \%)$. Temperature was $25 \pm 2{ }^{\circ} \mathrm{C}$ for $8 \mathrm{~h}$ of sun light without shading and relative humidity of $60 \%$. Plants were watered with $700 \mathrm{~mL}$ of water per $\mathrm{m}^{3} /$ day and nourished with nutrient solution composed of NPK: $10-10-10$ at concentration of $1.0 \mathrm{~g} \mathrm{~L}^{-1}$ of water (w/v). It was possible to obtain seeds suitable for planting 60 days after cultivation.

\section{Inoculation in vitro}

Sunflower seed were previously washed in running water with a brush, sterilized sequentially in $80 \%$ calcium hypochlorite solution and $70 \%$ alcohol solution for 5 minutes.

Plants culture were inoculated in Murashige and Skoog medium ${ }^{18}$ and standard mixture of POPs $\left(2 \mu \mathrm{g} \mathrm{mL}^{-1}\right)$ was added to this culture. The experiments were carried out under sterile condition. Plant pots were maintained at $25 \pm 2{ }^{\circ} \mathrm{C}$ during a photoperiod of $8 \mathrm{~h}$, wherein were illuminated by fluorescent lamp of $3000 \mathrm{Lux}\left( \pm 38 \mu \mathrm{mol} \mathrm{m} \mathrm{m}^{-2} / \mathrm{s}^{-1}\right.$; $20 \mathrm{~cm}$ positioned 20 inches from the pot cultures top).

After 30 days, plants were harvested then aerial and root components were separated and dried at room temperature in a desiccator containing silica gel under vacuum. Subsequently, the samples were weighed, grinded, sieved, packaged in polyethylene bottles and stored in a freezer $\left(-20^{\circ} \mathrm{C}\right)$ until the moment of extraction, which does not exceed $72 \mathrm{~h}$.

\section{Extraction and clean-up of sunflower and water samples}

\section{Sunflower}

An amount of $10.0 \mathrm{~g}$ of plant sample previously dried in an oven at $60{ }^{\circ} \mathrm{C}$ for $2 \mathrm{~h}$ were transferred to a beaker glass and extracted using $50 \mathrm{~mL}$ of a mixture of $\mathrm{n}$-hexane/toluene (50:50; v/v) in an ultrasonic bath for $5 \mathrm{~min}$.

The resulting extract was filtered on Buchner funnel using Whatman filter paper, $n^{\circ} 60$, concentrated in a rotaryevaporator under reduced pressure at $50{ }^{\circ} \mathrm{C}$, solubilized in $2 \mathrm{~mL}$ of $\mathrm{n}$-hexane/toluene (50:50; v/v) and then submitted to a clean-up step.

The clean-up of the extract was performed using activated Florisil column (Sigma-Aldrich, 60-100 mesh size) to eliminate interferences, matrix effects and also optimize the recovery of the analytes. Firstly, the glass column packed with $15 \mathrm{~g}$ of Florisil activated at $240{ }^{\circ} \mathrm{C}$ for $4 \mathrm{~h}$ and topped with $1 \mathrm{~cm}$ of anhydrous sodium sulfate was washed with $20 \mathrm{~mL}$ of hexane. Then, the extract was transferred to the column and eluted with $50 \mathrm{~mL}$ of ethyl acetate/hexane solution (50:50, v/v). The eluate collected was concentrated to $5 \mathrm{~mL}$ in a rotary vacuum evaporator at $45^{\circ} \mathrm{C}$ and evaporated to dryness under a gentle stream of purified nitrogen gas.

Immediately before analysis, the final volume of the extract was reconstituted in $1.0 \mathrm{~mL}$ of ethylacetate/hexane solution $(50: 50, \mathrm{v} / \mathrm{v})$ and analyzed by GC/MS.

In studies of recovery for sunflower samples (root and aerial parts), were performed at three levels: $0.2 ; 2.0$ and $10.0 \mathrm{ng} \mathrm{g}^{-1}$ by adding an appropriate volume of a standard working solution to $10.0 \mathrm{~g}$ of blank plants.

\section{Water}

$500 \mathrm{~mL}$ of a water sample were transferred to a separating funnel and extracted with 3 portions of $100 \mathrm{~mL}$ of $\mathrm{n}$-hexane/toluene solution 50:50 (v/v). Then, the organic extracts were added and concentrated to a volume of approximately $20 \mathrm{~mL}$ in a rotary evaporator under reduced pressure at $50{ }^{\circ} \mathrm{C}$. The extract was concentrated to dryness under nitrogen flow 5.0. The final volume of the extract was adjusted to $1.0 \mathrm{~mL}$ with ethyl acetate / hexane solution $(50: 50, \mathrm{v} / \mathrm{v})$ previously the experiment and then analyzed by GC/MS.

The studies of recovery for water samples, were performed at two levels: 0.1 and $1.0 \mu \mathrm{g} \mathrm{L}^{-1}$ by adding an appropriate volume of a standard working solution to $500 \mathrm{~mL}$ of water Milli Q.

\section{Analysis}

The analysis was performed on an Agilent Technologies series 7890A gas chromatograph with a 5975C Agilent Technologies mass selective ion detector (quadrupole) 5975C Agilent Technologies and a 100\% dimethylpolysiloxane DB1 fused silica capillary column (50 $\mathrm{m} \times 0.22 \mathrm{~mm} \times 0.2 \mu \mathrm{m})$. The carrier gas was purified helium applied at flow rate of $1.19 \mathrm{~mL} \mathrm{~min}^{-1}$. One microliter of sample was injected into the GC-MS in splitless mode, using an injection time of $1 \mathrm{~min}$, with the injection temperature set at $250{ }^{\circ} \mathrm{C}$. The oven temperature for the OCP analysis was programmed from 85 to $195^{\circ} \mathrm{C}$ at a heating rate of $3.5{ }^{\circ} \mathrm{C} \mathrm{min}^{-1}, 195$ to $280{ }^{\circ} \mathrm{C}$ at a rate of $5^{\circ} \mathrm{C} \mathrm{min}^{-1}$, where it was held for $10 \mathrm{~min}$. The analysis was conducted in the Selective Ion Monitoring (SIM) mode and the mass spectrometer parameters were: impact ionization voltage $70 \mathrm{eV}$; ion source temperature 230 ${ }^{\circ} \mathrm{C}$; transfer line $300{ }^{\circ} \mathrm{C}$; electron multiplier voltage $1200 \mathrm{~V}$; solvent delay 2.9 min; electron scan rate $1.5 \mathrm{scan} \mathrm{s}^{-1}$.

Quantitative determination of the POPs in the samples was carried out by the external standard method, using peak area integration parameters. Two calibration curves for 24 pollutants were made at five calibration levels, from 1.0 to $10.0 \mu \mathrm{g} \mathrm{L}^{-1}$ and 0.1 to $1.3 \mu \mathrm{g} \mathrm{L}^{-1}$ 
and all the standard calibration curves fit within the acceptable limits of the linearity criterion (data shown in Table 1).

\section{RESULTS AND DISCUSSION}

\section{Quality Assurance}

The evaluation of sample background was analyzed by GC/ MS with the solvents used to prepare the standard solutions. This procedure was performed in order to maintain the quality of results and detect possible contaminants, which may affect the final results.

An integrated validation study was developed to quantify 24 pollutants in water and sunflower samples in order to guarantee the phytoremediation results.

The limit of detection (LOD) of individual target molecules was determined by the concentration of analysis in a sample that produced a peak with a signal-to-noise ratio $(S / N)$ of 3 . The limit of quantification (LOQ) for all the target molecules was based on the GC/MS performance and background noise levels under laboratory conditions. These parameters were determined by analyzing procedural blanks in the same bath, which were consistent $(\mathrm{RSD}<$ $30 \%$ ). The LOQ was calculated and established at three times the standard deviation, considering the blank level, and the results of each sample, analysis showed about $95 \%$ certainty (Table 1 ). The values obtained for the limits of detection and quantification are in accordance with the literature for the majority of POPs studied. ${ }^{19,20}$

The precision and accuracy of the method were investigated on the recovery of replicate testing and coefficient of variation. The relative recovery tests were performed using the analyte to all blank samples, including sunflower and water.

For water samples the evaluations were carried out in two concentration levels established in about 2 to 10 times the value of the limit of quantification $\left(0.1\right.$ and $\left.1.0 \mu \mathrm{g} \mathrm{L}^{-1}\right)$ (Table 1).

In studies of fortification for sunflower samples (root and aerial parts), recovery tests were performed at three levels: $0.2 ; 2.0$ and $10.0 \mathrm{ng} \mathrm{g}^{-1}$, all being prepared in triplicate steps (Table 2).

\section{Phytoremediation using Sunflower}

Phytoremediation has shown to be a powerful tool for cleaning environmental matrices to reduce human and animal exposure toward potential carcinogens as POPs and other contaminants..$^{21-24}$

For a long time, it was believed that root microorganisms were the main responsible for xenobiotics metabolism. However, the advance of in vitro studies has shown that plant cells can metabolize a variety of xenobiotics in the absence of microorganisms. These studies allow the analysis of cellular and molecular plant cells responses without microorganism interference. Moreover, tissue cultures enable uniform uptake of contaminants, because the absorption is facilitated by the absence of wax, cuticle, epidermis, endodermis, etc. ${ }^{8}$

Table 1. Retention times $\left(\mathrm{t}_{\mathrm{R}}\right)$, limits of detection (LOD, $\mu \mathrm{g} \mathrm{L} \mathrm{L}^{-1}$ ), limits of quantification (LOQ, $\mu \mathrm{g} \mathrm{L}^{-1}$ ), recovery (\%) and determination coefficient of the studied POPs for water samples

\begin{tabular}{|c|c|c|c|c|c|}
\hline \multirow{2}{*}{ POPs } & \multirow{2}{*}{$\operatorname{LOD}\left(\mu \mathrm{g} \mathrm{L}^{-1}\right)$} & \multirow{2}{*}{$\mathrm{LOQ}\left(\mu \mathrm{g} \mathrm{L}^{-1}\right)$} & \multicolumn{2}{|c|}{ Recovery (\%) } & \multirow{2}{*}{ Calibration Curve $r^{2}$} \\
\hline & & & $0.1 \mu \mathrm{g} \mathrm{L}^{-1}$ & $1 \mu \mathrm{g} \mathrm{L}^{-1}$ & \\
\hline 1- tetrachloro-m-xylene & 0.001 & 0.006 & $91.25(4.7)$ & $88.39(5.2)$ & 0.99934 \\
\hline $2-\delta-\mathrm{HCH}$ & 0.001 & 0.005 & $98.54(4.2)$ & $98.80(3.4)$ & 0.99892 \\
\hline 3- $\alpha-\mathrm{HCH}$ & 0.003 & 0.007 & $70.81(4.3)$ & $87.52(2.7)$ & 0.99927 \\
\hline 4- $\gamma-\mathrm{HCH}$ & 0.002 & 0.005 & $96.38(3.8)$ & $96.04(2.9)$ & 0.99853 \\
\hline $5-\beta-\mathrm{HCH}$ & 0.002 & 0.006 & $73.28(2.9)$ & $90.89(3.8)$ & 0.99781 \\
\hline 6- heptachlor & 0.003 & 0.008 & $65.35(3.2)$ & $87.06(4.2)$ & 0.99993 \\
\hline 7- aldrin & 0.002 & 0.005 & $59.95(3.5)$ & $76.34(4.5)$ & 0.99905 \\
\hline 8- heptachlor -epoxide & 0.001 & 0.012 & $79.44(3.4)$ & $98.12(3.6)$ & 0.99965 \\
\hline 9- trans-chlordane & 0.002 & 0.005 & $76.45(4.3)$ & $95.15(2.6)$ & 0.99753 \\
\hline 10- endosulfan alpha & 0.001 & 0.005 & $81.47(3.0)$ & $98.63(4.9)$ & 0.99756 \\
\hline 11- chlordane & 0.003 & 0.007 & $76.58(4.0)$ & $95.07(5.0)$ & 0.99926 \\
\hline 12- dieldrin & 0.001 & 0.005 & $86.06(4.4)$ & $107.93(4.7)$ & 0.99557 \\
\hline 13-4,4' DDE & 0.002 & 0.005 & $85.06(3.9)$ & $105.41(4.4)$ & 0.99728 \\
\hline 14- endrin & 0.003 & 0.006 & $81.44(5.7)$ & $98.36(4.6)$ & 0.98045 \\
\hline 15- endosulfan Beta & 0.002 & 0.005 & $89.42(4.3)$ & $106.78(2.5)$ & 0.9961 \\
\hline 16- $p, p^{\prime} \mathrm{DDD}$ & 0.003 & 0.007 & $95.48(4.1)$ & $109.69(3.1)$ & 0.99126 \\
\hline 17- endrin aldehyde & 0.004 & 0.010 & $82.20(4.7)$ & $92.50(3.6)$ & 0.99741 \\
\hline 18- endosulfan sulfate & 0.002 & 0.006 & $91.29(2.9)$ & $108.38(4.1)$ & 0.99687 \\
\hline 19- $p, p^{\prime} \mathrm{DDT}$ & 0.002 & 0.007 & $94.84(3.0)$ & $118.35(3.2)$ & 0.99848 \\
\hline 20- endrin ketone & 0.001 & 0.006 & $84.78(4.1)$ & $97.42(3.7)$ & 0.99827 \\
\hline 21- hexabromobenzene & 0.006 & 0.010 & $81.39(5.3)$ & $88.07(5.6)$ & 0.99957 \\
\hline 22- methoxychlor & 0.004 & 0.007 & $92.36(5.7)$ & $91.68(4.6)$ & 0.99914 \\
\hline 23-mirex & 0.004 & 0.010 & $81.15(3.8)$ & $99.86(2.9)$ & 0.99768 \\
\hline 24- decachlorobiphenyl & 0.003 & 0.011 & $85.77(3.2)$ & $105.39(4.2)$ & 0.99937 \\
\hline
\end{tabular}


Table 2. Results obtained for the limits of quantification (LOQ), recovery in three levels of fortification for sunflower matrix (root and aerial parts), and coefficient of variation (CV \%), experiments carried out in triplicate

\begin{tabular}{|c|c|c|c|c|c|c|c|}
\hline \multirow{3}{*}{ POPs } & \multirow{3}{*}{$\begin{array}{c}\text { LOQ (RSD) } \\
\quad\left(\text { ng. } \mathrm{g}^{-1}\right)\end{array}$} & \multicolumn{6}{|c|}{ Recovery (\%) (CV) } \\
\hline & & \multicolumn{3}{|c|}{ root } & \multicolumn{3}{|c|}{ aerial } \\
\hline & & $0.2 \mathrm{ng} \mathrm{g}^{-1}$ & $2 \mathrm{ng} \mathrm{g}^{-1}$ & $10 \mathrm{ng} \mathrm{g}^{-1}$ & $0.2 \mathrm{ng} \mathrm{g}^{-1}$ & $2 \mathrm{ng} \mathrm{g}^{-1}$ & $10 \mathrm{ng} \mathrm{g}^{-1}$ \\
\hline 1- tetrachloro-m-xylene & $0.04(4.22)$ & $84.72(4.9)$ & $90.18(5.4)$ & $88.06(3.6)$ & $102.35(3.9)$ & $100.93(5.8)$ & $98.70(4.5)$ \\
\hline $2-\delta-\mathrm{HCH}$ & $0.03(4.45)$ & $95.21(5.4)$ & $88.32(6.1)$ & $81.36(4.4)$ & $88.41(3.3)$ & $92.91(6.3)$ & $88.52(5.1)$ \\
\hline 3- $\alpha-\mathrm{HCH}$ & $0.01(3.24)$ & $88.17(6.1)$ & $93.21(3.9)$ & $90,22(4.8)$ & $90,15(6.2)$ & $88.25(3.8)$ & $91.46(4.2)$ \\
\hline 4- $\gamma-\mathrm{HCH}$ & $0.05(4.06)$ & $78.34(4.6)$ & $88.54(3.3)$ & $95.70(5.3)$ & $79.05(5.6)$ & $83.64(4.7)$ & $88.25(3.9)$ \\
\hline $5-\beta-\mathrm{HCH}$ & $0.07(5.32)$ & $93.49(3.2)$ & $91.03(3.5)$ & $80,25(3.7)$ & $92.54(3.9)$ & $89.05(5.9)$ & $91.18(3.4)$ \\
\hline 6- heptachlor & $0.06(4.48)$ & $86.90(3.9)$ & $102.14(5.3)$ & $94.72(3.9)$ & $89.47(4.2)$ & $91.22(4.6)$ & $96.46(3.7)$ \\
\hline 7- aldrin & $0.07(5.69)$ & $68.17(3.7)$ & $67.22(6.2)$ & $66.28(5.1)$ & $65.21(3.9)$ & $62.34(5.7)$ & $60,38(5.4)$ \\
\hline 8- heptachlor -epoxide & $0.05(6.22)$ & $83.91(5.0)$ & $89.17(5.5)$ & $90,47(4.7)$ & $91.65(4.6)$ & $90,28(4.3)$ & $93.69(5.1)$ \\
\hline 9- trans-chlordane & $0.05(4.13)$ & $91.67(3.8)$ & $87.31(4.9)$ & $91.69(5.3)$ & $87.20(4.9)$ & $89.18(4.9)$ & $93.85(3.8)$ \\
\hline 10- endosulfan alpha & $0.03(6.55)$ & $89.12(5.3)$ & $92.09(4.2)$ & 89.18 (4.6) & $84.35(3.9)$ & $94.56(6.1)$ & $91.22(4.1)$ \\
\hline 11- chlordane & $0.04(3.97)$ & $87.52(4.7)$ & $103.44(5.7)$ & $93.22(5.2)$ & $88.11(5.1)$ & $94.77(5.4)$ & $96.30(3.9)$ \\
\hline 12- dieldrin & $0.07(5.20)$ & $90.36(3.8)$ & $91.07(3.8)$ & $89.69(4.8)$ & $94.36(4.8)$ & $104.61(4.2)$ & $102.38(3.7)$ \\
\hline 13-4,4' DDE & $0.05(4.84)$ & $92.11(4.9)$ & 88.28 (3.6) & $94.85(4.5)$ & $91.55(5.5)$ & $90.39(5.8)$ & $93.66(4.8)$ \\
\hline 14- endrin & $0.07(6.13)$ & $81.23(5.3)$ & $91.58(4.9)$ & $95.67(3.3)$ & $92.39(5.3)$ & $94.11(3.9)$ & $95.89(5.3)$ \\
\hline 15- endosulfan Beta & $0.06(5.51)$ & $78.20(4.8)$ & $101.34(6.3)$ & $97.89(5.5)$ & $87.06(4.7)$ & $91.23(4.4)$ & $90.26(4.7)$ \\
\hline 16- $p, p^{\prime} \mathrm{DDD}$ & $0.04(6.03)$ & $91.33(4.5)$ & $92.37(5.7)$ & $97.26(4.8)$ & $88.25(6.2)$ & $93.06(5.3)$ & $94.11(5.0)$ \\
\hline 17- endrin aldehyde & $0.07(5.22)$ & $81.52(5.9)$ & $90.19(3.4)$ & $96.81(5.2)$ & $83.41(5.9)$ & $91.55(4.7)$ & $86.32(3.9)$ \\
\hline 18- endosulfan sulfate & $0.01(6.34)$ & $90.36(3.7)$ & $105.69(5.6)$ & $95.63(4.3)$ & $92.87(3.8)$ & $98.70(5.8)$ & $99.17(4.5)$ \\
\hline 19- $p, p^{\prime} \mathrm{DDT}$ & $0.03(6.28)$ & $83.44(4.6)$ & $93.19(5.3)$ & 92.55 (4.6) & $85.31(5.1)$ & $91.86(4.9)$ & $90.60(3.7)$ \\
\hline 20- endrin ketone & $0.05(6.37)$ & $87.60(4.8)$ & $89.64(4.4)$ & $87.91(5.8)$ & $94.25(4.9)$ & $93.24(4.8)$ & $101.09(3.8)$ \\
\hline 21- hexabromobenzene & $0.06(5.42)$ & $81.39(4.2)$ & $83.69(5.3)$ & $90.56(5.4)$ & $88.07(5.6)$ & $90.64(5.2)$ & $96.31(4.4)$ \\
\hline 22- methoxychlor & $0.05(6.21)$ & $90.45(6.3)$ & $93.66(5.8)$ & $88.77(4.5)$ & $89.71(4.8)$ & $92.36(5.0)$ & $97.25(4.8)$ \\
\hline 23- mirex & $0.02(4.12)$ & $90.07(5.3)$ & $95.12(4.9)$ & $90.29(3.9)$ & $89.14(4.7)$ & 97.55 (3.6) & $90.89(4.3)$ \\
\hline 24- decachlorobiphenyl & $0.03(5.88)$ & $88.25(6.2)$ & $89.22(5.8)$ & $92.67(4.6)$ & $87.93(5.9)$ & $90.36(4.5)$ & $93.43(4.9)$ \\
\hline
\end{tabular}

This study was performed to investigate the ability of the plant Helianthus annuus L (sunflower) upon the removal and degradation of 24 persistent organic pollutants under in vitro conditions in order to isolate the effects of arbuscular mycorrhizal fungi present in the soil. Our data indicated that 16 of the 24 evaluated compounds showed results of remediation using sunflower both in root and in aerial compartments (Figure 1). The highest accumulation of pollutants was observed in the roots, which agrees with the current literature. ${ }^{25}$

Many authors associate this buildup to the presence of arbuscular mycorrhizal fungi in the roots, which increases plant contact surface with soil. ${ }^{26}$

Verma \& Arya $^{27}$ stated that these fungi are responsible for remediation process and the transference of pollutants could contaminate host plants. In contrast, other authors suggested that not only fungi, but plants rhizosphere helps in phytoremediation process. ${ }^{28}$

This study was conducted under in vitro and sterile conditions, so it was not possible to infer about theses interactions or associations, because all living organisms were removed during the sterilization process. In vitro culture is a valuable tool for phytoremediation research, since the process circumvent some limitations imposed by the use of intact plants.

The accumulation of POPS in sunflower roots ranged from $9.4 \%$ for 2,4,5,6-tetrachloro-m-xylene and $87.3 \%$ for 4,4'-DDT (Figure 1). Roots, fruits, seeds and sprouts are drainage organs; consequently phloem vessels contribute with the spread of residues in plants. The hypothesis that relates the root build up to the contact with polluted culture medium is inconsistent due to plants anatomy and morphology as a layer of impermeable cells isolates the roots. ${ }^{29}$ The most likely hypothesis of POPs accumulation is the direct transport from the roots to the xylema through apoplastic and symplastic movement and subsequent translocation to other organs, similarly to water and nutrient absorption. ${ }^{30}$

Naturally, non polar pollutants can be solubilized in water and absorbed by plants. Matsumoto et al. ${ }^{31}$ proposed that root eliminated compounds of low molecular weight, such as citric acid, organic acids and proteins can increase POPs solubility. ${ }^{32}$ as well as by the increased desorption resulting from the action of the root exudates. ${ }^{33}$

Several studies have showed hydrophobic compounds found in leaves and fruits ${ }^{34,35}$ such as polychlorinated biphenyls, ${ }^{35-37}$ DDT and its metabolites,${ }^{38}$ chlordane, ${ }^{39}$ hexachlorobenzene, ${ }^{40}$ heptachlor, ${ }^{41,42}$ and heptachlor epoxide. ${ }^{43}$

In this work, the obtained data showed an accumulation of $15.2 \%$ of $\gamma-\mathrm{HCH}$ and $24.6 \%$ for $\delta-\mathrm{HCH}$ in sunflower roots. Processes described in the literature without results for sunflower such as dechlorination, metabolizing compounds and generation of metabolites derived from the degradation of the molecule, ${ }^{44,45}$ may be related to the results obtained for endosulfan alpha. In this research, the authors studied the bioremediation endosulfan with the use of 
Phytoremediation in the root and aerial compartments

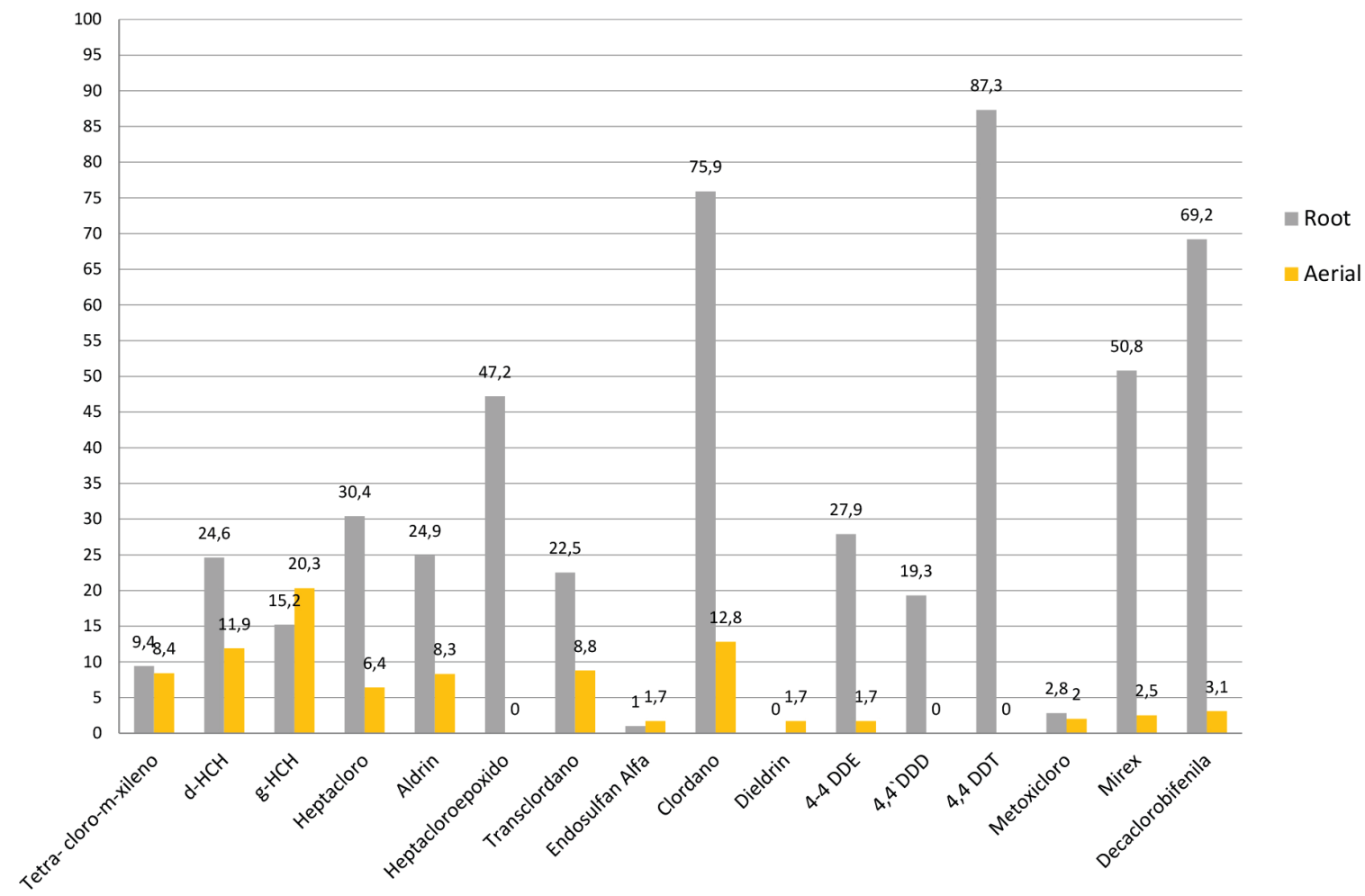

Figure 1. Results obtained for phytoremediation process (\%) using Helianthus annuus L (sunflower) in the root and aerial compartments

bacteria and fungi describing its degradation in three final products such as endosulfan lactone, endosulfan dimethylene and endosulfan monoalcohol, suggesting biotransformation routes to generate metabolites and breakdown products.

Studies have focused on plant/pollutant dynamics and bioconcentration in plant tissues. Pollutant chemical properties such as octanol-water partition coefficient, also the vapor pressure of organic pollutants and temperature are related to pollutant mobility and solubility in water. ${ }^{46,47}$ The Table 3 presents the solubility in water, soil organic carbon-water partitioning coefficient $\left(K_{\mathrm{oc}}\right)$ and the n-octanol-water partition coefficient $\left(K_{\text {ow }}\right)$, for studied POPs.

Organic contaminants, such as HCHs, are accumulated in the roots essentially as a result of two different processes: (i) uptake and translocation $^{48,49}$ of compounds with low hydrophobicity with log $K_{\text {ow }}$ values between 0.5 and 3.5 ; and (ii) adsorption in roots tissues. ${ }^{50}$ Whereas $\delta$-HCH and $\gamma-\mathrm{HCH}$ isomers have $\log K_{\mathrm{ow}}$ values of 4.14 and 3.72 respectively, the two processes can be considered possible. Beside it soil organic carbon content $\left(K_{\mathrm{oc}}\right)$ correlates positively with $K_{\text {ow }}$ and is an important factor to attract lipophilic substances.

It was observed accumulation of $\mathrm{HCH}$ isomers in the root and root surface absorption (hydrophobic partition) can be considered the major route of contamination by this pollutant.

Adsorption occurs through reversible partition of hydrophobic contaminant and hydrophobic surfaces (or cuticle composed of hydrophobic cell wall). ${ }^{51}$ This process is affected by the amount of compound available and lipids present in this fraction.

Briggs et al. ${ }^{52}$ and Burken and Schnoor ${ }^{49}$ developed experimental relationship based on $\log K_{\text {ow }}$ values to predict organic pollutants uptake by plants. According to their models, only "moderately hydrophobic" compounds $\left(0.5<\log K_{\text {ow }}<4.5\right)$ would be significantly absorbed and translocated with in plant tissues.

The study verified effective absorption of POPs with $\log K_{\text {ow }}$ ranging from 4.50 to 6.91 . Sunflower phytoremediation process efficiently detected heptachlor, aldrin, heptachlor epoxide, transchlordane, chlordane, dieldrin, DDE, DDT, methoxychlor, mirex and decachlorobiphenyl. These compounds of low $K_{\text {ow }}$ and $K_{\text {oc }}$ were found in higher concentrations in aerial compartment of the plant, except chlordane, aldrin and heptachlor. Although the well-known $K_{\text {ow }}$ predictions could explain the behavior of the most studied compounds, our results suggest that the uptake of some POPs should consider the absorption and translocation process related to displacement speed of ions on xylem.

The relationship between molecular characteristics such as solubility in water and coefficients as $K_{\text {ow }}$ and $K_{\text {oc }}$ can be helpful to understand what happens in a remediation process, but it is not enough to explain all the processes involved in an experimental system.

It was not possible to study metabolites and their possible degradation routes in this work. However, it was found many different chlorinated compounds of the studied POPs that could be derived from adverse reactions or degradation of sunflower. The study of remediation process of 24 compounds is challenging, since there are many variables and interferences. A future research will be required to evaluate the remediation of each pollutant.

\section{CONCLUSION}

Plant tissue cultures showed an important role in phytoremediation research of POPs and promoted substantially the understanding of sunflower metabolism. Beside it the experimental convenience and speed compared with phytoremediation conventional systems, the present study showed the capacity of the sunflower to metabolize the POPs pollutants without the effect of arbuscular mycorrhizal fungi.

Obtained results suggest that the accumulation of some POPs in sunflower should consider the absorption and translocation process owing to displacement speed of ions on xylem, despite of predicted solubility, $\log K_{\text {ow }}$ and $\log K_{\text {oc. }}$. 
Table 3. Parameters of the studied POPs solubility in water, $\log K_{\text {ow }}$ and $\log K_{\text {oc }}{ }^{53}$

\begin{tabular}{|c|c|c|c|}
\hline POPs & Solubility in water $\left(\mu \mathrm{g} \mathrm{mL}^{-1}\right)$ & $\log K_{\text {ow }}$ & $\log K_{\text {oc }}$ \\
\hline 1- tetrachloro-m-xylene & Not available & Not available & 4.90 \\
\hline $2-\delta-\mathrm{HCH}$ & 0.20 & 4.14 & 3.80 \\
\hline $3-\alpha-\mathrm{HCH}$ & 2.00 & 3.82 & 3.57 \\
\hline 4- $\gamma-\mathrm{HCH}$ & 0.20 & 3.72 & 3.00 \\
\hline $5-\beta-\mathrm{HCH}$ & 1.50 & 3.78 & 3.57 \\
\hline 6- heptachlor & 0.18 & 5.44 & 4.40 \\
\hline 7- aldrin & 0.01 & 6.50 & 4.69 \\
\hline 8- heptachlor -epoxide & 0.06 & 5.00 & 4.90 \\
\hline 9- trans-chlordane & 1.37 & 6.00 & 5.50 \\
\hline 10- endosulfan alpha & 0.41 & 4.65 & 4.03 \\
\hline 11- chlordane & 0.01 & 6.00 & 4.78 \\
\hline 12- dieldrin & 0.20 & 5.20 & 4.08 \\
\hline 13- 4,4' DDE & 0.12 & 6.51 & 4.70 \\
\hline 14- endrin & 0.23 & 5.20 & 4.06 \\
\hline 15- endosulfan beta & 0.23 & 4.34 & 4.13 \\
\hline 16- $p, p^{\prime} \mathrm{DDD}$ & 0.09 & 6.02 & 5.18 \\
\hline 17- endrin aldehyde & 0.02 & 4.80 & 4.7 \\
\hline 18- endosulfan sulfate & 0.48 & 3.77 & 4.03 \\
\hline 19- $p, p^{\prime} \mathrm{DDT}$ & 0.02 & 6.91 & 5.18 \\
\hline 20- endrin ketone & 0.25 & 5.20 & 4.53 \\
\hline 21- hexabromobenzene & 0.01 & 5.73 & 4.8 \\
\hline 22- methoxychlor & 0.10 & 4.83 & 3.36 \\
\hline 23- mirex & 0.08 & 6.89 & 7.38 \\
\hline 24- decachlorobiphenyl & 0.01 & 8.22 & 8.09 \\
\hline
\end{tabular}

Furthermore, it allows an extrapolation in the phytoremediation study: prevention of sunflower production for nutrition purpose in POPs contaminated areas and usage of sunflowers after remediation process for biomass and biodiesel energy production.

\section{REFERENCES}

1. http://www.epa.gov/international-cooperation/persistent-organicpollutants-global-issue-global-response, accessed December 2017.

2. Torres, J. P. M.; Lailson-Brito, J.; Saldanha, G. C.; Dorneles, P.; Silva, C. E. A.; Malm, O.; Guimarães, J. R.; Azeredo, A.; Bastos, W. R.; da Silva, V. M. F.; Martin, A. R.; Claudio, L.; Markowitz, S.; J. Braz. Chem. Soc. 2009, 20, 1175 .

3. McCutcheon, S. C.; Schnoor, J. L.; Phytoremediation: Transformation and Control of Contaminants; John Wiley \& Sons, Inc.: New Jersey, 2003.

4. Chekroun, K. B.; Sánchez, E.; Baghour, M.; Int. J. Environ. Res. Public Health. 2014, 1, 19.

5. Chibuike, G. U; Obiora, S. C.; Int. J. Environ. Sci. 2013, 4, 223.

6. Nwadinigwe, A. O.; Onyeidu, E. G.; Pol. J. Environ. Stud. 2012, 21, 171.

7. Flocco, C. G.; Giulietti, A. M.; In Phytoremediation methods in biotechnology; Willey, N., ed.; vol. 23, Wiley Humana: New Jersey, 2007.

8. Doran, P. M.; Biotechnol. Bioeng. 2009, 103, 60.

9. CENPES - Centro de Pesquisas e Desenvolvimento: http://www. biodieselbr.com/noticias/mamona/insucesso-mamona-petrobras-apostagirassol-05-05-08.htm, acessed December 2017.

10. Brazil Seeds, Sunflower: Producer's Manual, São Paulo, 2001, 30 p.
11. January, M. C.; Cutright, T. J.; Van Keulen, H. W. R.; Chemosphere 2007, 70, 531.

12. Stojanović, M.; Pezo, L.; Lačnjevac, Č.; Mihajlović, M.; Petrović, J.; Milojković, J.; Stanojević, M.; Int. J. Phytoremediation 2016, 18, 527.

13. Martínez-Fernández, D.; Barroso, D.; Komárek, M.; Environ. Sci. Pollut. Res. Int. 2016, 23, 1732.

14. Shaheen, S. M.; Rinklebe, J.; Environ. Geochem. Health 2015, 37, 953.

15. Gujarathi, N. P.; Haney, B. J.; Park H. J.; Wickramasinghe, S. R.; Linden, J. C.; Biotechnol. Prog. 2005, 21, 775.

16. Martins, C. D. C.; Liduino, V. S.; Oliveira, F. J. S.; Sérvulo, E. F. C.; Intern. J. Engin. Technol. 2014, 14, 1.

17. Salehi-Lisar, S. Y.; Deljoo, S.; Harzandi, A. M.; Intern. J. Phytoremediation 2015, 17, 1145.

18. Murashige, T.; Skoog, F.; Physiol. Plant 1962, 15, 473.

19. Prates, C. B.; Gebara, S. S.; Ré-Poppi, N.; Quim. Nova 2011, 34, 1260.

20. Wang, Y.; Zhang, Q.; Lv, J.; Liu, H.; Li, G.; Jiang, G.; Chemosphere 2007, 68, 1683 .

21. Cunningham, S. D.; Anderson, A. P.; Plant Physiol. 1996, 110, 715.

22. Cunningham, S. D.; Anderson, T. A.; Schwab, A. P.; Hsu, F. C.; Adv. Agron. 1996, 56, 56.

23. Binet, P.; Portal, J. M.; Leyval, C.; Soil Biol. Biochem. 2000, 32, 2011.

24. Joner, E. J.; Leyval, C.; Environ. Sci. Technol. 2003, 37, 2371.

25. Mahjoub, B. In Biomass for Sustainable Applications: Pollution Remediation and Energy; Gaspard, S., Ncibi, M. C., eds.; The Royal Society of Chemistry: Cambridge, 2014, pp. 106-143.

26. Rillig, M. C.; Mardatin, N. F.; Leifheit, E. F.; Antunes, P. M.; Soil Biol. Biochem. 2010, 42, 1189. 
27. Verma, R. K.; Arya, I. D.; Mycorrhiza 1998, 8, 113

28. Muratova, A.; Dubrovskaya, E.; Golubev, S.; Grinev, V.; Chernyshova, M.; Turkovskaya, O.; J. Plant Physiol. 2015, 188, 1.

29. Liese, W.; The Anatomy of Bamboo Culms, INBAR Technical Report $\mathrm{N}^{\circ} 18$, International Network for Bamboo and Rattan, Beijing, 1998, $204 \mathrm{p}$

30. Collins, C.; Fryer, M.; Grosso, A.; Environ. Sci. Technol. 2006, 40, 45.

31. Matsumoto, E.; Kawanaka, Y.; Yun, S. J.; Oyaizu, H.; Appl. Microb. Biotechnol. 2009, 84, 205.

32. Johgenson, J. E.; Environ. Health Perspect. 2001, 109, 113.

33. White, J. C.; Environ. Toxicol. Chem. 2001, 20, 2047.

34. Hülster, A.; Muller, J. F.; Marschner, H.; Environ. Sci. Technol. 1994, $28,1101$.

35. Inui, H.; Wakai, T.; Gion, K.; Kim, Y. S.; Eun, H.; Chemosphere 2008, $73,1602$.

36. White, J. C.; Parrish, Z. D.; Isleyen, M.; Gent, M. P. N.; IannucciBerger, W.; Eitzer, B. D.; Kelsey, J. W.; Mattina, M. I.; Intern. J. Phytoremediation 2006, 8, 63.

37. Zimmer, D.; Kiersch, K.; Jandl, G.; Water Air Soil Pollut. 2010, 211, 299.

38. Mitton, F. M.; Gonzalez, M.; Peña, A.; Miglioranza, K. S.; J. Hazard. Mater. 2012, 203, 62.

39. Mattina, M. I.; Eitzer, B. D.; Iannucci-Berger, W.; Lee, W.-Y.; White, J. C.; Environ. Toxicol. Chem. 2004, 23, 2756.

40. Ecker, S.; Horak, O.; Chemosphere 1994, 29, 2135.
41. Lichtenstein, E. P.; Schulz, K. R.; Skrentny, R. F.; Stitt, P. A.; J. Econ. Entomol. 1965, 58, 742.

42. Purnomo, A. S.; Putra, S. R.; Shimizu, K.; Kondo, R.; Environ. Sci. Pollut. Res. Int. 2014, 21, 113.

43. Campbell, S.; Arakaki, A. S.; Li, Q. L.; Int. J. Phytoremediation 2009, $11,28$.

44. Odukkathil, G.; Vasudevan, N.; J. Environ. Manage. 2016, 165, 72.

45. Mitton, F. M.; Gonzalez, M.; Monserrat, J. M.; Miglioranza, K. S.; Chemosphere 2016, 148, 300.

46. Kataoka, R.; Takagi, K.; Kamei, I.; Kiyota, H.; Sato, Y.; Environ. Sci. Technol. 2010, 44, 6343.

47. San Miguel, A.; Ravanel, P.; Raveton, M.; J. Hazard. Mater 2013, 60, 244.

48. Schnoor, J. L.; Licht, L. A.; Mccutcheon, S. C.; Wolfe, N. L.; Carreira, L. H.; Environ. Sci. Technol. 1995, 29, 318.

49. Burken, J. G.; Schnoor, J. L.; Environ. Sci. Technol. 1998, 32, 3379.

50. Yi, Z.; Zheng, L.; Guo, P.; Bi, J.; Ecotoxicol. Environ. Saf. 2013, 91, 156.

51. Pivetz, B. E.; Phytoremediation of Contaminated Soil and Ground Water at Hazardous Waste Sites, EPA/540/S-01/500, United States Environmental Protection Agency, Washington, 2001.

52. Briggs, G. G.; Bromilow, R. H.; Evans, A. A.; Pestic. Sci. 1982, 13, 495.

53. http://itepsrv1.itep.nau.edu/itep_course_downloads/DAI/ LAKESDEMOS\%20(D)/IRAP-h/EPAGuides/Volume2/AppA-A3. PDF, accessed December 2017. 